RESEARCH ARTICLE

\title{
HOW POLICE OVERCOMES MONEY LAUNDERING? STUDY ANALYSIS OF ROLE OF CENTRAL JAVA REGIONAL POLICE DEPARTMENT ON MONEY LAUNDERING CASE
}

\author{
Djoko Pamungkas ${ }^{l_{凶}}$ \\ ${ }^{1}$ Central Java Regional Police Department, Indonesia \\ $\bowtie$ djoko.pamungkas@gmail.com
}

\section{HOW TO CITE}

Pamungkas, D. (2020). How Police Overcomes Money Laundering? Study Analysis of Role of Central Java Regional Police Department on Money Laundering Case. Journal of Law and Legal Reform, 1(1), 25-34. DOI: https://doi.org/10.15294/jllr.vlil.35416

\begin{abstract}
The main purpose of this research is to describe the role of the Indonesian National Police in tackling the rampant crime of the Money Laundering Criminal Act through conducting investigations on it carried out by the Central Java Regional Police Department and analyzing factors that influence the implementation of investigation. This is descriptive research according to the problem and purpose of the study. In analyzing the study used sociological juridical research methods with qualitative research types. The research emphasized that investigation of money laundering works effectively and quickly based on Article 74 Law of Money Laundering, and it carried out through systematic work management needed to support efficient and effective work so the handling of a case can run faster and measurable. The aim is to facilitate investigators in investigate of wealth from criminal acts, which are inseparable from the collection of evidence instruments in the investigation of all the 183 Jo 184 Criminal Procedure Code and article 73 Law on Criminal Procedure. 2) Factors that influence the investigator to investigate criminal acts of money laundering are legal factors, legal action, legal reasoning or facilities that support the enforcement of law and elements of the community.
\end{abstract}

Keywords: Indonesian National Police; Investigation; Law Enforcement; Money Laundering; Prevention 


\section{TABLE OF CONTENTS}

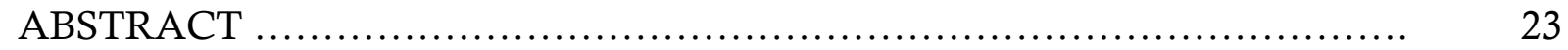

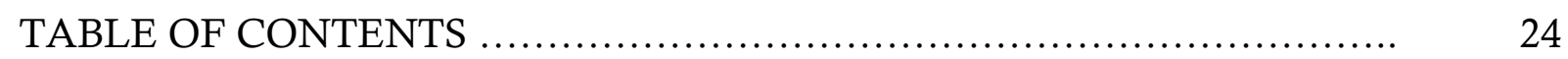

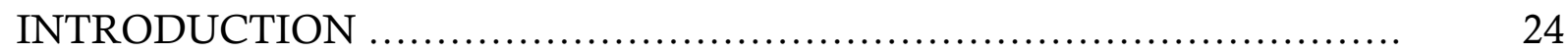

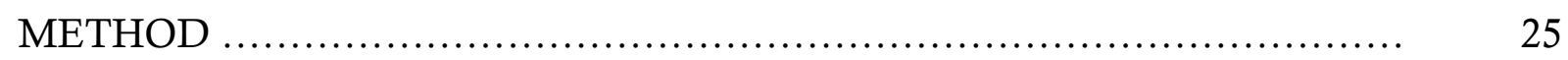

INVESTIGATION OF MONEY LAUNDERING CASES ....................... 26

I. THE ROLE OF CENTRAL JAVA POLICE DEPARTMENT ............... 26

A. Money Laundering Investigation in Central Java Regional Police to 26

Prevent Money Laundering in Central Java Area ...........................

B. Factors Affected Investigator in Investigation of Money Laundering ........ 27

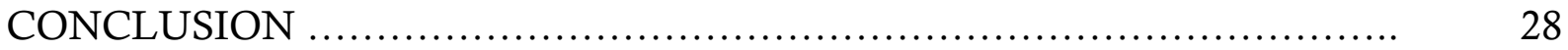

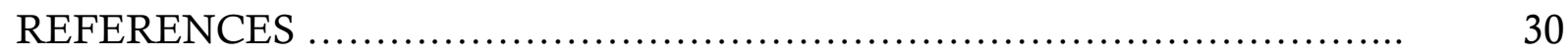

\section{INTRODUCTION}

Money laundering recently is a world phenomenon and become an international challenge. Money laundering generally is defined as a process to change crime from corruption, drugs, gambling, smuggling, and other serious crime, so those crime results made visible and bright as a clean wealth because its origin has been concealed.

So many countries have difficulties in preventing money laundering, include Indonesia. Even Indonesia already applying anti-money laundering regime approach since $17^{\text {th }}$ April 2002 that signed by ratification of Law Number 15 of 2002 about money laundering criminal crime that revised by Law Number 25 of 2003 (Money laundering criminal offenses of law) and changed again into law number 8 of 2010 about Prevention and Eradication of Money Laundering Crimes but International Narcotics Control Strategy Report (INCSR) that released by Bureau for International Narcotics and Law Enforcement Affairs, United States Department of State on March 2003, still includes Indonesia in a row of Asia Pacific major laundering countries.

From many reports and publications, the proliferation of money laundering criminal crimes in Indonesia based on some factors they are free foreign exchange regime that allows anyone to have an international exchange, and uses it to many activities but not required give it to Indonesian Bank. Not only that, the weak of law enforcement and the lack of professional law enforcement officials, moreover, the demands of globalization, especially global developments in the financial services sector as a result of the liberalization process, have allowed criminals to enter open financial markets. Technology advances in information system especially the using of the internet, make the organized crime possible that done by transnational organized crime become easy to do (Arifin, 2018; Muhtada \& Arifin, 2019).

The provisions of banking secrets often applied strictly though money laundering law is already minimalized those provisions. It is possible to use a pseudonym or anonymous by the bank customer that much influenced by the lack of 
know your customers' principle (KYC) application by the financial services industry (Arifin, 2018; Wibowo, 2018).

It is possible to money laundering practice done by layering, which makes the detection of money laundering activity challenging by law enforcement. In this case, the money that has been placed in a bank is transferred to another bank, both banks in that country and other countries. While the transfer was carried out several times, so it can no longer be traced by law enforcement and legal provisions regarding the confidentiality of the relationship between the lawyer and his client, and between the accountant and his client.

Yenti Garnasih (2003) stated that there are at least two major problems in the implementation of this anti-money laundering law enforcement, namely bank secrecy, and verification. From the aspect of bank confidentiality, customers have the right to privacy and are protected based on bank confidentiality law. While from the element of proof, money laundering crime is not a single crime, but a double. The demand for an act of money laundering requires proving two forms of misconduct at once, namely proving money laundering (follow-up crime) itself and proving that the money is illegal. In other words, enforcement of the Money Laundering Crime cannot be implemented if there are no other supporting elements.

\section{METHOD}

The research used empirical legal research, which conducted on the Regional Police Department of Central Java, Indonesia (POLDA Jateng). The study is examined the role of the Regional Police department of Central Java in overcoming money laundering cases. The problems of this research as follow:

1. How the implementation of money laundering crime investigation in central java police regional to prevent money laundering crime in central java?

2. What is the factor that affected the investigator to investigate money laundering crime?

\section{INVESTIGATION OF MONEY LAUNDERING CASES}

\section{THE ROLE OF THE CENTRAL JAVA POLICE DEPARTMENT}

A. Money Laundering Investigation in Central Java Regional Police to Prevent Money Laundering in Central Java Area

According to "the principle of fair and quick, simple, low cost and free, honest and not in favor of applying the provisions of the law in all areas of justice," the rest of the investigators feel more capable and useful in the field of investigation. Investigation of Money Laundering Crime (TPPU) in Law Number 8 of 2011 in the matter of Prevention and Eradication of Money Laundering crime, Laws regulated in Chapter VIII section. Explanation of Article 73: 
What is meant by "criminal investigations" refers to officials from the Ministry of Corruption (KPK), Legislation and Authorities in the Ministry of Law Republic Indonesia, the Ministry of Justice and Directorate of Law Republic Indonesia and the Directorate General of the Republic Indonesia.

The task of investigators in handling money laundering crimes in Central Java Regional Police according to IPDA Arif Setyawan as Panit I of Unit 2 of Subdit 4 of Ditreskrimsus of Central Java Regional Police is receiving complaints from the public about the existence of Money Laundering Crime, receiving reports from the Central Financial Reporting and Analysis Center (PPATK) as well as conducting investigations of Money Laundering crime can be carried out in accordance with criminal investigations of misconduct, finding evidence of commencement. Enough criminal acts of money laundering when conducting investigations of criminal acts according to their authority. Whereas Article 75 is:

In the case of investigators finding evidence of commencement that is sufficient for money laundering crime and notifying the original criminal act, the investigator combines investigation of unprecedented criminal action with the investigation of criminal laundering and informs him of the original criminal act.

These opinions and arguments are based on the general explanation of Law Number 8 of 2010, which states: In its development, the act of launder was increasingly complex, crossed the boundaries of state jurisdiction, and used a more varied mode, utilized the financial system, increased the number of financial institutions, increased the number of financial institutions. Article 69 UU PPTTPU:

To be able to carry out investigations, prosecutions, and inspections in the field of justice for acts of laundering, it is not compulsory to prove that it is more before legal action.

Article 75 emphasizes the evidence for the inception of sufficient money laundering crime cases and the origin of money laundering. Where can sufficient evidence be obtained from the Investigation Procedure?

The results of the recent investigation of the money laundering crime are 6 cases and it is showed that money laundering was only three cases, and three other cases. Thus, of the 6 TPPU cases reported by PPATK, only three cases had fulfilled the elements of the TPPU article to proceed to Public Prosecutor. While from three other examples not constituting money laundering, according to IPDA Arif Setyawan as Unit 2 Sub Directorate of Ditreskrimsus Central Java Police, can be broken down into 3 cases fulfilling elements and evidence, and three cases do not qualify as suspicious transaction reports (Suspicious Transaction Report) because complete evidence or sanctions do not support it. 
Based on the stipulations in Article 83 and Article 86 of the Law Money Laundering Crime, the investigator should protect reporters and witnesses. This issue highlighted that the definition of bank secrecy is unclear. With the enactment of Law No. 10/1998 on November 10, 1998, which amended in Law Number 7 of 1992, the terms "financial condition" and lack of clarity but still lack of clarification (Hakim, 2015; Huesin 2004; Amirullah 2003; Arifin \& Choirinnisa, 2019). There is, as seen in the definition of bank secrecy in Law No. 10 of 1999 concerning the Amendment of Money in Law No. 7 of 1992 concerning Banking which states, that the confidentiality of the bank is everything related to the information "with regard to" and.

Does everything in the case of saving funds and deposits must be kept secret by bank, for example the customer's name, address, account number, card number, hobbies, family customers and so on, who the customer deposits funds must keep secret and whether all customers store either bank account numbers, hobbies, family customers etc.

\section{B. Factors Affected Investigator in Investigation of Money Laundering}

Based on the interview with Ipda Arif Setiawan as Panit I Unit 2 Subdit 4 Ditreskrimsus Central Java Regional Police, Factors affected investigator in investigate of money laundering are:

1. Law

2. Law enforcement

3. facilities that support law enforcement

4. community

One of the difficulties, in order to prevent investigation of money laundering crime, is Juridical constraints, that is as regulated in article 72 of money laundering law but need a long time to get allowed from the officials such as a bank. Besides, only in a short period, the lender can move the money from the deposit of one other bank in practice. The implementation of rules governing the confidentiality of bank secrecy at the level of investigation has not yet been made expertly.

This is in accordance with the view of Husein (2004), that even though Law No. 8 of 2012 claims that there is a "general interest" can be used as a reason to open up or breakthrough provisions of bank secrecy, in the implementation of it in the field, there is a "general interest" that can be used as a reason to open up or break through the provisions of the bank secrecy, in the implementation of it in the field, as well as the progress and the relative effectiveness. Bank services that continue to develop make taxpayers, debtors (guarantor) and suspects/defendants in the calculation of minutes can only immediately move and account for other parties such as inter persons or their relatives.

Based on an interview with Ipda Arif Setiawan as Panit I Unit 2 Subdit 4 Ditreskrimsus Central Java Regional Police, efforts to deal with obstacles faced by investigators in money laundering cases are as follows:

1. Against the juridical obstacles

a. Bank secrecy provisions 
While repeating the judiciary's most profound sentences concerning the existence of regulations regarding bank secrecy, the agreement is made by bringing parties between investigators, banks, and customers into one place.

b. Obligation to protect reporters and witnesses.

To overcome legal problems which relate to the provision of obligation to protect reporters and witnesses in the investigation of money laundering crime, carried out by way of: first, making a report on criminal acts of washing the money as an immediate finding of criminal investigations. Secondly, protection was carried out secretly by not project was done in a manner, it was not immediately published, and third, with consideration of security and safety reasons, the taxation was placed at National Police Headquarters under the supervision of the police.

c. The perception of investigators about money laundering crime was not yet perfect.

Meanwhile, to overcome the obstacles that judicially related to investigators' existence perception regarding the crime of money laundering.

d. The information from the PPATK is not yet complete.

To overcome the constraints that are juridical in relation to conflict with PPATK mediation form, they are not complete, carried out by investigating how to coordinate with PPATK to present the testimonies through PPATK mediation so that they are not perfect, carried out by examining how to coordinate with PPATK to give the proofs through PPATK mediation so that they are not incomplete, carried out by investigating how to coordinate with PPATK. After that, the investigators conducted an examination of them by conducting interviews to determine who could be accused of witnessing and witnessing, which then carried out involuntary remedies.

2. non-juridical constraints

a. the reporter is not necessarily a victim

To overcome the non-legal issues that relate to the presence of reporters in criminal acts of laundering which have not yet been determined to be victims of crime, they have been carried out by providing guarantees to the complainant, that is, by doing criminal acts that are reported to be a crime.

b. The ability of Human Resources in Humanity is limited investigations.

To overcome the constraints that are non-legal experts related to the ability of human resources limited human investigators, they are carried out utilizing improving the capability of human resources.

1) Sending investigations to take part in a seminar on the crime of laundering.

2) Sending investigators to follow the special education investigation of leisure laundering.

3) Sending students to follow up on the study program in the legal market program.

4) Send out investigators to follow training in foreign countries such as United States Association. 


\section{CONCLUSION}

The implementation of criminal investigations on money laundering in the Central Java Regional Police in context of tackling the Criminal Acts of the TPPU in the Central Java region can run the effectiveness of investigating the law in investigating the Money Laundering Crime, based on the thought that Article 74 of Law on Criminal Procedure Code in Central Java region can carry out effective investigations in investigating the law in conducting Money Laundering Crime. Wealth originating from Criminal Acts, because the process of tracing Assets is a part that is inseparable from the process of collecting Evidence in investigation accordance with article $183 \mathrm{Jo}$ 184 of the Criminal Procedure Code and article 73 concerning legal evidence Law. However, there are still legal norms (norms) in regulating the authority of the Investigator related to the implementation of Article 69 Article 74 and Article 75 of Law No. 8 of 2010, that there are still multiple interpretations, namely that investigators are not obliged to prove their original Criminal Acts.

Factors that affected investigators in conducting criminal investigations of financial laundering are law factors, law enforcement factors, facility factors, or facilities that support law enforcement and community factors. The obstacles that arise in the investigation of money laundering crimes consist of:

1) judicial obstacles

a) Provisions concerning bank secrecy

b) Obligations to protect reporters and reactions

c) Perceived investigations on TPPU are not yet perfect

d) Information from PPATK is incomplete

2) Non-judicial obstacles, such as:

a) The reporter has not however been victimized

b) The number of investigations and capabilities of HRM is limited.

As for the scope of handling the financial problems of the investigators in the case of money laundering, the following facts are as follows:

a. Against the legalistic control

1) The provisions of bank secrecy are carried out by bringing together parties between investigators, banks, and customers in one place.

2) The obligation to protect reporters and witnesses is carried out by making the report of money laundering and direct laundering of police as collection, and protection is carried out in the same manner or placed in Police Headquarters under the supervision and taking care of the police directly.

3) Perceptions of investigations regarding MPTP have not been perfect, carried out by holding socialization of Law No. 8 of 2010 concerning TPPU to investigators and issuing a Special Guidance on Money Laundering Crime.

4) Information from PPATK is not complete, yet it is carried out through conducting coordination with PPATK to present witnesses through PPATK mediation so that they do not feel unrestricted concerning the police. 
b. Against the control which is non-legalistic

1) Reporting has no determined victims yet, carried out by providing guarantees to the reporter by making sure that planted actions reported are a direct discovery of the policy.

2) Limited human resource capacity for students is carried out by increasing the ability of human resources to investigate through seminars, advanced studies, or overseas training such as in the United States.

The author also suggests that the effective implementation of money laundering investigation and inclusion in the justice sector is a fast, cheap and straightforward grave. The government needs to establish an institution that supports the money laundering crime investigation, such as the PPATP in every region/province. To avoid interpreting and due to lack of clarity on duties and authority of the Money Laundering Act, by placing articles that regulate authority and regulations such as implicit regulation, authority, and regulation. Other authorities are more effective in implementing the intended authority. In optimizing TPPU investigations, it is necessary to increase the number of investigative personnel who have the qualifications to investigate Money Laundering in every institution/agency that has been given the authority to carry out investigations into Money Laundering and to intensify training/education activities.

\section{REFERENCES}

Amirullah, A. (2003). Money Laundering Tindak Pidana Pencucian Uang. Malang: Bayu Media Publishing.

Arifin, R., \& Choirinnisa, S. (2019). Pertanggungjawaban Korporasi dalam Tindak Pidana Pencucian Uang dalam Prinsip Hukum Pidana Indonesia (Corporate Responsibility on Money Laundering Crimes on Indonesian Criminal Law Principle).JURNAL MERCATORIA, 12(1), 43-53. DOI: http://ojs.uma.ac.id/index.php/mercatoria/article/view/2349

Arifin, R. (2018). Law Enforcement in Banking Criminal Act Involving Insiders. Jambe Law Journal, 1(1), 55-90. https://doi.org/https://doi.org/10.22437/jlj.1.1.55-90

Garnasih, Y. (2003). Kriminalisasi Pencucian Uang (Money Laundering). Jakarta: Fakultas Hukum Universitas Indonesia.

Garnasih, Y. (2007). Kebijakan Kriminalisasi dalam Pemberantasan Tindak Pidana Pencucian Uang. Mimbar Hukum, 19(2), 167-181.

Hakim, A.L. (2015). Crime of Money Laundering and Modus Business Law in Perspective. Jurnal Hukum DE'RECHTSSTAAT, l(1), 33-46. DOI: http://dx.doi.org/10.30997/jhd.vlil.410 
Husein, Y. (2004). Tindak Pidana Pencucian Uang (Money Laundering) Dalam Perspektif Hukum Internasional. Indonesian Journal of International Law, 1(2), 342358. http://journal.ui.ac.id/index.php/IJIL/article/viewFile/2726/2108

Muhtada, D., \& Arifin, R. (2019). Penal Policy and the Complexity of Criminal Law Enforcement: Introducing JILS 4(1) May 2019 Edition. JILS (Journal of Indonesian Legal Studies), 4(01), l-6. https://doi.org/10.15294/jils.v4i01.30189

Republic of Indonesia. (1981). Act Number 8 of 1981 of the Republic of Indonesian on the Code of Criminal Procedure (Indonesian Criminal Law Procedure Code)

Wibowo, M. H. (2018). Corporate Responsibility in Money Laundering Crime (Perspective Criminal Law Policy in Crime of Corruption in Indonesia). JILS (Journal of Indonesian Legal Studies), 3(2), 213-236. DOI: https://doi.org/10.15294/jils.v3i02.22740 


\section{QUOTE}

\section{Corruption, money laundering, and tax evasion are global problems, not just challenges for developing countries.}

Sri Mulyani Indrawati

Former of Financial Minister of Republic of Indonesia 